\title{
Awareness on antibiotic usage among undergraduate medical students in a teaching hospital, Guntur
}

\author{
Bheemesh Naidu Mattam ${ }^{1 *}$, D. L. N. Prathyusha ${ }^{2}$, Santhi S. Yedurupaka ${ }^{2}$, Sai V. Yerram²
}

${ }^{1}$ Department of Pharmacology, Katuri Medical College and Hospital, Guntur, Andhra Pradesh, India

${ }^{2}$ Department of Pharmacology, Maharajah's Institute of Medicine Sciences, Vizianagaram, Andhra Pradesh, India

Received: 19 April 2018

Revised: 20 May 2019

Accepted: 22 May 2020

\section{*Correspondence:}

Dr. Bheemesh Naidu Mattam,

Email: bheemesh6@gmail.com

Copyright: (C) the author(s), publisher and licensee Medip Academy. This is an open-access article distributed under the terms of the Creative Commons Attribution Non-Commercial License, which permits unrestricted non-commercial use, distribution, and reproduction in any medium, provided the original work is properly cited.

\begin{abstract}
Background: Antibiotics are the mainstay treatment of most of the infectious diseases. Inappropriate and irrational use of antimicrobial agents has led to increase in the development of antimicrobial resistance. Medical students are a part of health care system and they must be aware of increasing antibiotic resistance as they are the future prescribers. The objectives of the study were to assess the awareness on antibiotic usage and its resistance among medical students and to study the perception on antibiotic medication among medical students.

Methods: This was a cross-sectional, semi-structured questionnaire-based study. Questionnaire consists of 4 partssocio-demographic details, awareness on antibiotics and its resistance, knowledge on specific treatment of a disease, perception levels. Prior IEC approval was taken. The obtained data was statistically analyzed using Microsoft excel sheet.

Results: Among 230 participants, majority of the students have awareness on general antibiotic usage and $97.8 \%$ were having knowledge about antibiotic resistance. The main source of information on antibiotic resistance is identified as classroom teaching (67.8\%). $46.9 \%$ and $25.2 \%$ students correctly identified the drug of choice for treating enteric fever and community acquired pneumonia respectively.

Conclusions: Degrees of awareness on antibiotics and its resistance is found to be good. Antibiotic usage pattern is not on par with knowledge. Knowledge on specific treatment of infectious disease is found to be less. So, antibiotic teaching should be integrated with clinical subjects.
\end{abstract}

Keywords: Antibiotic usage, Antibiotic resistance, Clinical based learning

\section{INTRODUCTION}

Antibiotics are the mainstay treatment of most of the infectious diseases. These are the most frequently prescribed drugs, but they are often misused. ${ }^{1,2}$ In 2010 , India was the world's largest consumer of antibiotics for human health. ${ }^{3}$

Antibacterial resistance is the ability of bacteria to resist the effects of antibiotics acting against it. ${ }^{4}$ Resistance is a global public health threat, rapidly increasing in SouthEast Asian countries. ${ }^{5}$ In India, inappropriate and irrational use of antimicrobial agents has led to increase in development of antimicrobial resistance. ${ }^{6}$ New resistance mechanisms are emerging and spreading globally, threatening our ability to treat common infectious diseases, resulting in prolonged illness, disability, and death. ${ }^{7}$ A project commissioned by the British government estimates the near-future global toll of antibiotic resistance as 10 million deaths per year. ${ }^{8}$

Medical students are a part of health care system and they must be aware of antibiotic usage and resistance as they are the future prescribers. So, this present study was 
conducted to assess the awareness on usage of antibiotics and antibiotic resistance among medical students.

\section{Objectives}

The objectives of the study were to assess the awareness on antibiotic usage and its resistance among medical students and to study the perception on antibiotic medication among medical students.

\section{METHODS}

This study was a cross-sectional and semi structured questionnaire-based study. Voluntary participants of $3^{\text {rd }}$ and $4^{\text {th }}$ year students of Katuri Medical College and Hospital (KMCH) were taken into the study. Institutional Ethics Committee (IEC) clearance was obtained prior to the beginning of study. Strict anonymity was assured. Details of the study and intention behind the survey were explained clearly before administering the questionnaire. Informed consent was taken and questionnaires were administered.

Questionnaire consists of 4 sections.

Section-1: Socio-demographic characters of the students like age, gender and year of study

Section-2: It includes questions on general awareness on antibiotics and antibiotic resistance.

Section-3: It attributes to the assessment of knowledge on specific treatment of common diseases.

Section-4: It focused on perception levels of the students.

The data obtained was entered in Microsoft Excel Sheet and descriptive analysis of the socio demographic data was done accounting the age, gender, and year of study. For dichotomous variables like gender and year of study, results were expressed in terms of frequencies and percentages and for continuous variables like age, results were expressed as mean and standard deviation.

Results of awareness on antibiotics and antibiotic resistance and specific treatment of common disease were expressed in frequencies and percentages. Outcomes of perception levels were assorted as agree/yes and disagree/no and the percentages were calculated.

The final result obtained was categorized as good $(75 \%$ and above), moderate (50-74\%) and poor (50\%).

\section{RESULTS}

A total of 230 students participated in the study out of which $58.7 \%$ were $4^{\text {th }}$ year and $41.3 \%$ were $3^{\text {rd }}$ year. Out of them $72 \%(n=165)$ were females and $28 \%(n=65)$ were males. Mean age of the participants was 20 years with S.D (standard deviation) of $0.98 .80 \%$ of the participants used antibiotics in the last year, and $48.7 \%$ of the total students used them for 1-2 times in last year (Table 1).

Table 1: Socio-demographic characteristics.

\begin{tabular}{|lc|}
\hline Details & $\mathbf{N}(\%)$ \\
\hline Gender & $165(72)$ \\
\hline Female & $65(28)$ \\
\hline Male & $20.66 \pm 0.98$ \\
\hline Age (mean $\mathbf{S D})$ & $95(41.3)$ \\
\hline Year of study & $135(58.7)$ \\
\hline $3^{\text {rd }}$ year & \\
\hline $4^{\text {th }}$ year & $184(80)$ \\
\hline Antibiotic use in last year & $46(20)$ \\
\hline Yes & $112(48.7)$ \\
\hline No & $46(20)$ \\
\hline No. of times antibiotics were taken in last year \\
\hline $1-2$ & $26(11.3)$ \\
\hline $3-5$ & \\
\hline$>5$ & \\
\hline
\end{tabular}

Table 2: Awareness on antibiotics and its resistance.

\begin{tabular}{|lc|}
\hline Questions & $\begin{array}{l}\text { Correct } \\
\text { response (\%) }\end{array}$ \\
\hline $\begin{array}{l}\text { Antibiotics can kill good bacteria } \\
\text { present in our body }\end{array}$ & $220(95.6)$ \\
\hline $\begin{array}{l}\text { Antibiotics can cause secondary } \\
\text { infections by killing good bacteria }\end{array}$ & $189(82.2)$ \\
\hline $\begin{array}{l}\text { Antibiotics are indicated to } \\
\text { reduce any kind of pain and } \\
\text { inflammation }\end{array}$ & $182(79.1)$ \\
\hline $\begin{array}{l}\text { Antibiotics can cause untoward } \\
\text { effects (e.g., allergic reactions) }\end{array}$ & $212(92.2)$ \\
\hline $\begin{array}{l}\text { Antibiotic resistance is a } \\
\text { phenomenon for which a } \\
\text { bacterium loses its sensitivity to } \\
\text { an antibiotic }\end{array}$ & $225(97.8)$ \\
\hline Source of information on antibiotic resistance \\
\hline \begin{tabular}{l} 
Classroom teaching \\
\hline Books
\end{tabular} & $156(67.8)$ \\
\hline Others & $60(26.1)$ \\
\hline
\end{tabular}

Table 3: Awareness on specific treatment.

\begin{tabular}{|ll|}
\hline Infectious disease & $\begin{array}{l}\text { Correct } \\
\text { response (\%) }\end{array}$ \\
\hline Enteric fever & $108(46.9)$ \\
\hline Community acquired pneumonia & $58(25.2)$ \\
\hline
\end{tabular}

Majority of the students were aware of general antibiotic usage. $97.8 \%$ students were having knowledge about antibiotic resistance. $67.8 \%, 26.1 \%$ of the total students knew about antibiotic resistance through classroom teaching, books respectively and $4 \%$ of the total students knew about it through other sources. $95.6 \%, 82.2 \%$ of the students were aware that antibiotics can kill good bacteria of our body and thus cause secondary infections respectively. $79.1 \%$ know the indications of antibiotics, but more than $92 \%$ knew that antibiotics can cause untoward effects (Table 2). 
Table 4: Perception of medical students on antibiotic usage.

\begin{tabular}{|c|c|c|}
\hline \multirow{2}{*}{ Questions } & \multicolumn{2}{|c|}{ Response (\%) } \\
\hline & Agree (yes) & Disagree (no) \\
\hline $\begin{array}{l}\text { Misuse of antibiotic can lead to loss of sensitivity of an } \\
\text { antibiotic to a specific pathogen }\end{array}$ & 224 (97.4) & $6(2.6)$ \\
\hline If symptoms improve before the completion of full course, you can stop taking it. & $18(7.8)$ & $212(92.2)$ \\
\hline $\begin{array}{l}\text { Antibiotic resistance is associated with increased morbidity, mortality and } \\
\text { prolonged hospitalization of the patient }\end{array}$ & $212(92.2)$ & $18(7.8)$ \\
\hline $\begin{array}{l}\text { Imparting education on "Rational use of antibiotics" is } \\
\text { significant for UG medical students }\end{array}$ & $224(97.4)$ & $6(2.6)$ \\
\hline Antibiotic teaching in pharmacology should be integrated with clinical subjects & $227(98.7)$ & $3(1.3)$ \\
\hline Education on antibiotic resistance to the nurses and pharmacists is required & $225(97.8)$ & $5(2.2)$ \\
\hline Do you usually take antibiotic for cold or sore throat? & $74(32.2)$ & $156(67.8)$ \\
\hline Do you usually take antibiotic for fever & $82(35.6)$ & $148(64.4)$ \\
\hline Do you take antibiotics only when prescribed by the doctor? & $178(77.4)$ & $52(22.6)$ \\
\hline $\begin{array}{l}\text { Do you keep leftovers antibiotics at home because they might be useful in the } \\
\text { future? }\end{array}$ & $118(51.3)$ & $112(48.7)$ \\
\hline Do you use leftovers antibiotics without consulting your doctor? & $35(15.2)$ & $83(36)$ \\
\hline
\end{tabular}

$46.9 \%$ students correctly identified the drug of choice for treating enteric fever whereas $25.2 \%$ students identified the drug of choice for treating community acquired pneumonia (Table 3).

$98.7 \%$ of the students agreed that antibiotic pharmacology teaching should be integrated with clinical subjects. $97.4 \%$ students knew the effect of antibiotic misusage on a pathogen. $92.2 \%$ students were aware that antibiotics should not be stopped prior to the completion of its full course, even if the symptoms subside. $92.2 \%$ students opined that antibiotic resistance is associated with increased morbidity, mortality and prolonged hospitalization. $97.4 \%$ students agreed that education on the rational usage of antibiotics is significant for UG medical students and $97.8 \%$ students agreed that education on antibiotic resistance is to be extended to nurses and pharmacists as well. $67.8 \%, 64.4 \%$ students did not take antibiotics for cold or sore throat and fever respectively. $77.4 \%$ students agreed that they will take antibiotics only when prescribed by the doctor. $51.3 \%$ of the students kept leftover antibiotics at home for future use, and $15 \%$ of the total students used them without consulting doctor (Table 4).

\section{DISCUSSION}

In our study, $184(80 \%)$ students used antibiotics in the last year and $112(48.7 \%)$ students used 1-2 times, 46 (20\%) students used 3-4 times and 26 (11.3\%) students used $>5$ times, which was found to be higher when compared to Scaioli et al, study conducted in Italy in which $45.6 \%$ used antibiotics in the preceding year and $81.8 \%, 15.5 \%$ and $2.7 \%$ used $1-2,3-5,>5$ times respectively. ${ }^{9}$

Untoward effects of antibiotics are well known to $92.2 \%$ of the total participants which is similar to Scaioli et al study conducted in Italy in which it was $93.4 \% .{ }^{9} 92.2 \%$ of the students in our study know that antibiotic resistance can cause prolonged hospitalization and increases the mortality and morbidity. This was found to be higher than Sharma et al study $(82.5 \%)$ conducted in Rajasthan, India. $^{10}$

$97.4 \%$ of all the students participated have better understanding that inappropriate use of antibiotics can harm patients and cause antibiotic resistance, which is similar to Abbo et al study performed in US which showed almost all the students interviewed were aware of antibiotic resistance. ${ }^{11} 97.8 \%$ of the respondents agreed that, education on antibiotic resistance to the nurses and pharmacists is required which is more when compared to the study done by Sharma et al, in which only $50 \%$ agreed. ${ }^{10}$

$67.8 \%$ believed that antibiotics are not used against cold and sore throat which is more compared to $40 \%$ in 2013 Eurobarometer report on antibiotic resistance. ${ }^{12} 92.2 \%$ students believed that antibiotic should not be stopped till entire course is finished even if the symptoms subside.

98.7\% of students admitted that Antibiotic stewardship teaching in pharmacology should be integrated with clinical subjects. Similar results were found with Vasundara et al, study and Sharma et al, study in which $98 \%$ of the students believed the integration of Antimicrobial pharmacology with clinical subjects. $80 \%$ used antibiotics in the last year and $77.4 \%$ said that they buy antibiotics without a medical prescription, which implies that knowledge on antibiotics is not on par with their consumption which is detrimental to health care..$^{10,13}$

$95.6 \%, 82.2 \%$ of the participants agreed that antibiotics can kill good bacteria present in our body and thus causes secondary infections respectively. This is more when compared to Scaioli et al, study in which only $21.4 \%$ students admitted that antibiotics can kill good bacteria. ${ }^{9}$ 
51.3\% had kept left over antibiotics at home and $15.2 \%$ used them which is less than a global survey performed by Kardas et al, where $50 \%$ of the sample interviewed admitted having left over antibiotics. ${ }^{14}$

\section{CONCLUSION}

Proportion of antibiotic usage by UG medical students was found to be more but frequency of usage is less when compared to the similar studies conducted in countries like Italy and US. Antibiotic usage pattern is not on par with knowledge which must be overcome by initiating awareness programs on the rational use of antibiotics. Knowledge on specific treatment of infectious diseases is found to be less. So, Antibiotic teaching should be integrated with clinical subjects. Degree of awareness on antibiotics \& its resistance is found to be good.

Funding: No funding sources

Conflict of interest: None declared

Ethical approval: The study was approved by the Institutional Ethics Committee

\section{REFERENCES}

1. Chambers HF. General principles of antimicrobial therapy. In Goodman \& Gilman's The Pharmacological Basis of Therapeutics 11th edition. Editors: Brunton L, Parker K, Blumenthal D, Buxton I. New York, USA, Mc Graw Hill. 2006: 1095-1110.

2. World Health Organization (WHO) (2014) Antimicrobial Resistance. Global Report on Surveillance. Geneva: World Health Organization, 2014.

3. Lakshminarayan R, Chaudhury RR. Antibiotic Resistance in India: Drivers and opportunities for Action. PLoS Med. 2016;13(3):e1001974.

4. About Antimicrobial Resistance - Antibiotic/ Antimicrobial Resistance - CDC. CDC.GOV. 2017; Available at: https:/www.cdc.gov/drugresistance/ about.html/. Accessed on 3 January 2019.

5. World Health Organization, WHO's first global report on antibiotic resistance reveals serious, worldwide threat to public health. 10 September 2014; Available at: http://www.who.int/mediacentre/ news/releases/2014/amr-report/en. Accessed on 3 January 2019.
6. World Health Organization. Prevention and Containment of Antimicrobial resistance. Available at: http://www.ino.searo.who.int/LinkFiles/Other_ Content_WHD11-Seminar_Presentation-WRpdf. Accessed on 3 March 2018.

7. World Health Organisation (WHO), Antimicrobial Resistance, Factsheet, November 2016. Available at: http://www.who.int/mediacentre/factsheets/fs 194/en/ Accessed on 3 March 2018.

8. Genetic Literacy Project: Antibiotic resistance may be bigger problem than previously thought; Maryn McKenna; December 16, 2014. Available at: https:/geneticliteracyproject.org/2014/12/16/antibioti c-resistance-may-be-bigger-problem-than-previouslythought/. Accessed on 3 March 2018.

9. Scaioli G, Gualano MR, Gili R, Masucci S,Bert F, Siliquini R. Antibiotic Use: A Cross-Sectional Survey Assessing the Knowledge, Attitudes and Practices amongst Students of a School of Medicine in Italy. PLoS ONE. 2015;10(4):e0122476.

10. Sharma K, Jain P, Sharma A. Knowledge, attitude and perception of medical and dental undergraduates about antimicrobial stewardship. Indian J Pharmacol. 2015;47:676-9.

11. Abbo LM, Cosgrove SE, Pottinger PS, Pereyra M, Sinkowitz-Cochran R, Srinivasan A. Medical students' perceptions and knowledge about antimicrobial stewardship: how are we educating our future prescribers? Clin Infect Dis. 2013;57(5):631-8.

12. European Commission. Special Eurobarometer 407. Antimicrobial Resistance. Report (2013) Available at: http://ec.europa.eu/health/antimicrobial_resistance /docs/ebs_407_en.pdf Accessed 10 December 2014.

13. Vasundara K, Kanchan P, Pundarikaksha HP, Girish $\mathrm{K}$, Prassana S, Jyothi R. An imperative need to change pharmacology curriculum: A pilot survey. Indian J Pharmacol. 2010;42:420.

14. Kardas P, Pechère JC, Hughes DA, Cornaglia G. A global survey of antibiotic leftovers in the outpatient setting. Int J Antimicrob Agents. 2007;30(6):530-6.

Cite this article as: Mattam BN, Prathyusha DLN, Yedurupaka SS, Yerram SV. Awareness on antibiotic usage among undergraduate medical students in a teaching hospital, Guntur. Int J Basic Clin Pharmacol 2020;9:1011-4. 